\title{
AGRICULTURAL ENTERPRISES IN BULGARIA: STRUCTURAL FEATURES AND DEVELOPMENT
}

\author{
T. Atanassova-Kalaydzhieva*
}

\author{
Faculty of Economics, Trakia University, Stara Zagora, Bulgaria
}

\begin{abstract}
The aim of the present article is to study and analyze the present state of agricultural farms in Bulgaria, and to provide directions for their development. The following tasks have been set in order to accomplish this goal: to establish the main difficulties in farm functioning; to discover the factors with an impact on their development; to offer adequate measures for sustainable growth. The study encompasses the period from the beginning of the transition to market economy in the 1990s to the end of the first programme period after Bulgaria's accession to the EU. The sources of information used in the analysis include data from national statistics, agrarian reports from the Ministry of Healthcare and Food, literature by other authors, as well as our own research. Main conclusions: the agricultural reform in Bulgaria in the 1990s led to establishing a production structure of private agriculture farms; the latter is strongly polarized - with a large number of small size and few large size farms. Part of the small farms is maintained by people who have no other employment opportunities. Many of them start working with limited production resources and knowledge, they have an insufficient access to loans and professional training. These and several other factors obstruct successful farm functioning and decrease production results. Bulgaria's accession to the EU deepened the polarization between small and big agricultural farms. This process was also affected by the EU Common Agriculture Policy, and most of all - the single payment scheme per unit of used land area. To stimulate the growth and development of family agriculture business in Bulgaria, the state needs to provide special conditions: young people will require professional entrepreneurship culture, they must acquire experience in developing successful agricultural farms at home and abroad; cooperation with research institutions is needed, as well as preferential crediting, introduction of "green" production technologies, etc.
\end{abstract}

Key words: agricultural farms, size-based differentiation, standard output indicator, analysis, development.

\section{INTRODUCTION}

Farming enterprises in their diverse size differentiation (small, medium-sized and largescale) are the main agricultural production business in the economies of many countries. The average size of farms in the EU-28 is 16.1 ha of land (2013). There is a difference in the size between the old EU member states -15 countries (28.1 ha/farm) and the 13 countries (EU-13: 7.8 ha/farm) admitted in 2004 and 2007. Of these, $66 \%$ own less than 5 hectares of farmland, which represents $6.2 \%$ of the total utilized area in the EU-28, while 7\% cultivate more than 50 ha. Structural dualism is the most

*Correspondence to: Todorka AtanassovaKalaydzhieva, Faculty of Economics, Trakia University, Stara Zagora, Bulgaria pronounced in Bulgaria, Hungary, Slovakia and the Czech Republic, where there are few large farms and a large number of small family farms. (1). A significant number of the employed population finds their realization in the family form of agrarian business, which provides opportunities for personal realization and autonomy in making management decisions. In 2013, 97\% of all EU farms were one-holder farms (or family farms). The average size of family farms in the EU was increasing by $4 \%$ per annum in the period 2005 - 2013, with rates of increase in the new member states (EU-13) being $4.5 \%$ per year compared to the old Member States (EU- 15) $3.5 \%$. Large-scale corporate farms are $2.8 \%$ of all farms in the EU and they are owned by a legal entity. Another category is the cooperative 
farms (belonging to a group of people). They are about $0.7 \%$ of all farms in the EU. The number of people engaged in farming in the EU reached 22.2 million in 2013, many of whom work part-time.

The aim of this scientific research is to study and analyze the condition and structural features of agricultural farms in Bulgaria according to their size differentiation, and to present some directions for their development.

To achieve that aim the following aspects will be discussed: size-based differentiation of agricultural farms in the country; analysis of the main structural features of each farm size; putting forward measures for growth and sustainable development.

\section{SIZE DIFFERENTIATION OF AGRICULTURAL ENTERPRISES IN BULGARIA}

A number of factors have their impact on the size differentiation of farm enterprises: geographic location, soil typology, type of livestock, financial and institutional support conditions, farmers' traditions and attitudes, etc. There is a discussion in scientific literature on the main factors (indicators), and hence, on the limits for size differentiation of farms.

According to Davidova S., K.Thomson (2) the size of the farm may be determined by using its structural and economic size, the number of the animals raised, labour force participation and sales revenue. Small farms are defined by Eurostat and FAO as having agricultural area of less than 5 ha and this threshold is used in several publications Davidova (2,3); Galluzzo, (4), Papadopoulos (5), etc. The determination of size limit is influenced by geographical location, as the farm size is very heterogeneous in different regions and EU member states according to Hazell et al., (6) и Lowder et al. (7).

The total utilized area criterion is universal for the size differentiation of agricultural farms because it is easy to measure and allows comparisons in different regions and countries.In addition, other indicators may be used, such as: number of employees (full or part-time employment); number and type of products (specialization); annual sales revenue, etc. However, some of these indicators are associated with specific types of agrarian production and thus, it is more difficult to use a general differentiation of farms. For example, EFSA et al., use a threshold of 75 cows and
$80 \%$ annual family employment to set the threshold for a small dairy farm (8).

Agricultural farm differentiation is also related to the farmer's employment on the farm. These are subsistence farms (including semisubsistence ones) with a part-time employment; small market-oriented farms with year-round employment and large commercial enterprises (3).

According to Koteva N. and M. AtanasovaChopeva small agricultural farms in Bulgaria are divided in three groups: subsistence farmsup to 1 economic unit (EU), i.e. their standard output (SO) is up to EUR 1200; semisubsistence farms - from 1 to $4 \mathrm{EU}$, the SO being up to EUR 4800; small market-oriented farms - from 4 to $8 \mathrm{EU}$, the $\mathrm{SO}$ being up to EUR $9600(8,9)$.

According to the data of the Agricultural Accounting Information System in 2013 the most common in Bulgaria were the small market-oriented farms with an average size of about 63 decares, 46 decares of which are rented. They raise 4,3 animal units. These farms are located around the cities. The head of the family with the help of other family members carry out the production activity. The equivalent of full-time employment per year is 1,4 work units on average. The manager of the family farm is 52 years old. The average fixed assets per farm amount to EUR 11562 EUR, while the short-term assets amount to EUR 9160. Gross production per farm on annual basis amounts to EUR 8054, while the net value added amounts to EUR 5109 (10).

The analysis of literature shows that there is no single indicator for size differentiation of farm holdings. In the analysis below the standard output indicator (SO) of agricultural farms is used (11). It is determined for each crop and farm animal as an average monetary value of the output produced at farm-gate prices in the area. It is accepted that the indicator is calculated by EU member states per hectare or number of animals based on data for a reference period of 5 consecutive years. The indicator is used for determining the typology of farms in EU and is different from the cost price indicator. The total standard output of an agricultural enterprise is the sum total of the standard output of each agrarian product produced therein, multiplied by the corresponding number of hectares or heads of livestock. For the calculation of the same indicator in Bulgaria for 2016, data for the 
reference period 2011-2015 was used, the information having been collected from: product surveys of the Ministry of Agriculture and Food, prices of agricultural products, collected by NSI and the System for Agrarian Information, expert assessments, etc. According to the Standard output indictor (SO) agricultural enterprises in Bulgaria can be divided into the following groups: 1) Small subsistence farms up to 2 thousand EUR; 2) Small semisubsistence farms of 2-4 thousand EUR; 3) Small market-oriented farms of 4-15 thousand EUR; 4) Medium-sized market-oriented farms of 15-100 thousand EUR; 5) Large market oriented farms of 100-250 thousand EUR.

\section{AGRICULTURAL ENTERPRISES IN BULGARIA - STRUCTURAL FEATURES}

The small subsistence farms in Bulgaria are the largest group - 104898 (Table 1). Their
ATANASSOVA-KALAYDZHIEVA T. relative share of the total number of holdings is the largest $-52,2 \%$. Despite being the largest group, they generate only $2,6 \%$ of the total standard output (EUR) in the sector - Table 2. The average standard output per farm for the period amounts to EUR 931.

Small semi-subsistence farms are three times less in number - 34956 as compared to small subsistence farms, their relative share being $17,4 \%$. They account for $2,6 \%$ of the total standard output in the sector. Annual standard output per farm is EUR 2831, which is three times as much as small subsistence farms.

Small market-oriented farms are 36701 , their relative share being $18,2 \%$. They produce $7,4 \%$ of the total standard output in the country with an average of EUR 7640 per farm, i.e. 2,7 times as much as the semi-subsistence ones Tables $\mathbf{1}$ and 2.

Table 1. Number and relative share of agricultural enterprises in Bulgaria, based on size groups, 2016 (12-18)

\begin{tabular}{|l|l|r|r|}
\hline $\begin{array}{l}\text { Type of } \\
\text { agricultural enterprises } \\
\text { (AE) }\end{array}$ & $\begin{array}{c}\text { Size groups of AE, } \\
\text { based on Standard } \\
\text { output (EUR) }\end{array}$ & Number & $\begin{array}{r}\text { Relative } \\
\text { share } \\
(\%)\end{array}$ \\
\hline Small (Subsistence) & $<2000$ & 104898 & $\mathbf{5 2 . 2}$ \\
\hline Small (Semi-subsistence) & $>=2000<4000$ & 34956 & $\mathbf{1 7 . 4}$ \\
\hline \multirow{2}{*}{ Small (Market) } & $>=4000<8000$ & 22955 & $\mathbf{1 1 . 4}$ \\
\cline { 2 - 4 } & $>=8000<15000$ & 13746 & $\mathbf{6 . 8}$ \\
\hline \multirow{3}{*}{ Medium-sized (Market) } & $>=15000<25000$ & 8248 & $\mathbf{4 . 1}$ \\
\cline { 2 - 4 } & $>=25000<50000$ & 6675 & $\mathbf{3 . 3}$ \\
\cline { 2 - 4 } & $>=50000<100000$ & 3967 & $\mathbf{2 . 0}$ \\
\hline \multirow{2}{*}{ Large (Market) } & $>=100000<250000$ & 2676 & $\mathbf{1 . 3}$ \\
\cline { 2 - 4 } & $>=250000$ & 2893 & $\mathbf{1 . 4}$ \\
\hline TOTAL & & $\mathbf{2 0 1 0 1 4}$ & $\mathbf{1 0 0 , 0}$ \\
\hline
\end{tabular}

Source: Ministry of Agriculture and Food, Agrarian Statistics Department and author's calculations

Table 2. Total standard output and its relative share, based on groups of agricultural enterprises in Bulgaria, 2016 (12-18)

\begin{tabular}{|l|l|r|r|}
\hline $\begin{array}{l}\text { Type of } \\
\text { agricultural enterprises } \\
\text { (AE) }\end{array}$ & $\begin{array}{c}\text { Size groups of AE } \\
\text { based on Standard } \\
\text { output } \\
\text { (EUR) }\end{array}$ & $\begin{array}{c}\text { Total standard } \\
\text { production } \\
\text { thousands of } \\
\text { EUR) }\end{array}$ & $\begin{array}{c}\text { Relative } \\
\text { share } \\
(\%)\end{array}$ \\
\hline Small (Subsistence) & $>2000$ & 97642 & $\mathbf{2 . 6}$ \\
\hline Small (Semi-subsistence) & $>=2000<4000$ & 98956 & $\mathbf{2 . 6}$ \\
\hline \multirow{2}{*}{ Small (Market) } & $>=4000<8000$ & 130046 & $\mathbf{3 . 4}$ \\
\cline { 2 - 5 } & $>=8000<15000$ & 150391 & $\mathbf{4 . 0}$ \\
\hline \multirow{3}{*}{ Medium-sized } & $>=15000<25000$ & 158824 & $\mathbf{4 . 2}$ \\
\cline { 2 - 5 } & $>=25000<50000$ & 234070 & $\mathbf{6 . 2}$ \\
\cline { 2 - 5 } & $>=50000<100000$ & 273491 & $\mathbf{7 . 2}$ \\
\hline \multirow{2}{*}{ Large } & $>=100000<250000$ & 423013 & $\mathbf{1 1 . 2}$ \\
\cline { 2 - 5 } & $>=250000$ & 2210036 & $\mathbf{5 8 . 5}$ \\
\hline TOTAL & & $\mathbf{3 7 7 6 4 6 9}$ & $\mathbf{1 0 0 . 0}$ \\
\hline
\end{tabular}

Source: Ministry of Agriculture and Food, Agrarian Statistics Department and author's calculations 
Medium-sized farms are 18890 and their number is twice smaller than that of market-oriented farms. Their relative share from all agricultural enterprises in the country is $9,4 \%$, but they account for $17,6 \%$ of the total standard output in the sector. On average, one such farm produces standard output of EUR 35 277, which is 4,6 times as much as the standard production of small marketoriented farms. (Tables 1 and 2).

Large-scale agricultural enterprises constitute the smallest group - they are only 5569 (2016), their relative share being $2,7 \%$. This group accounts for $69,7 \%$ of the total standard output of the agrarian sector in Bulgaria. On average, one such farm produces standard output of EUR 472805 per year, which is 13 times as much as the SO in medium-sized farms (Tables 1 and 2).
ATANASSOVA-KALAYDZHIEVA T.

The difference in the number, relative share and standard output produced in small (subsistence, semi-subsistence and market-oriented), mediumsized and large-scale agrarian enterprises in Bulgaria is a result of different factors. The strongest impact has the agrarian production structure, imposed in the country in the 1990s because of the land reform. Two decades after the reform's completion there are many small and few relatively large farms in Bulgaria, the large-scale enterprises owing a significant part of the agricultural land. The low relative share of agricultural holdings in Bulgaria, handling 100 or more hectares of agricultural land, as compared to such holdings in the other EU member states, shows significant differences, existing in the organizational structure in our country (Figure1).

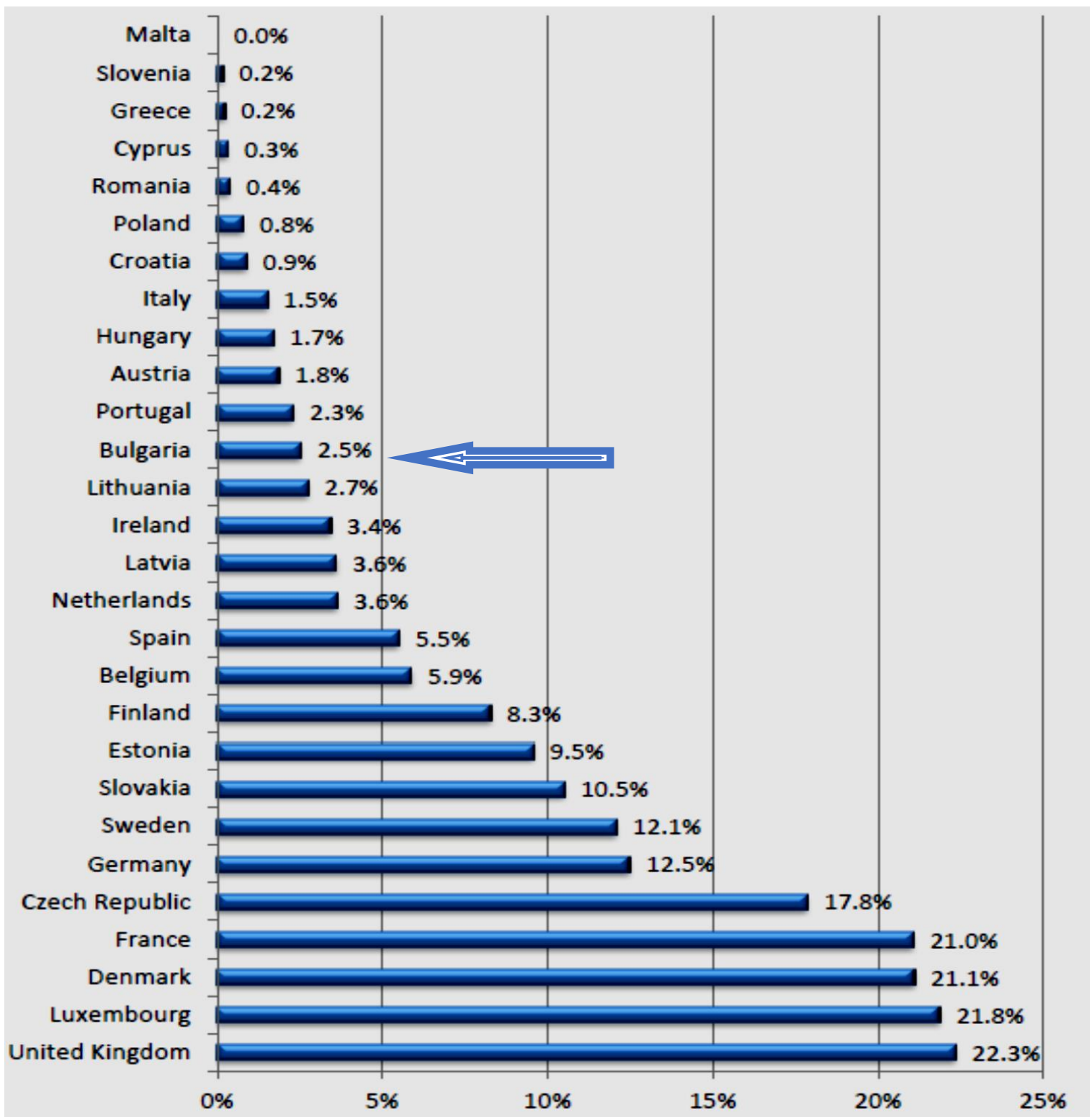

Figure 1. Relative share of agricultural enterprises owing 100 or more hectares agricultural land in EU member states, 2013

(Source: Eurostat) 
With the admission of Bulgaria as a full member of the European Union, the conditions for the development of farming enterprises change. The Common Agricultural Policy (CAP) and its mechanisms have strong influence on agrarian production. In the process of implementation of the Single Area Payment Scheme (SAPS) a small number of farms, mostly large-scale ones, benefit from it, receiving significant amounts of money from direct payments, while the small farms have no access to the scheme. In 2012 only $6 \%$ of the agricultural enterprises in Bulgaria received $80 \%$ of the total amount of direct payments; 20 of them were paid EUR 21,6 million (16, 17, 19).

In Bulgaria, there are regional disproportions in the localization of agricultural holdings from different size groups (Table 3 and Figure 2) The largest number of farms is located in the
ATANASSOVA-KALAYDZHIEVA T. South Central region - 63539 , followed by the Southwest region - 42 134. The number of farms in the other three regions is relatively small - Southeast (27 859), North Central (22 855) and Northeast (22 421), the number being the smallest in the Northwest Region (22 205). The difference between the last two is insignificant. In the Couth Central and Southwest regions mainly small subsistence (56,3\% and $60,4 \%$ respectively) and semisubsistence farms $(19,9 \%$ and $17,7 \%)$ are located. The number and relative share of small market-oriented farms in the South Central region- $15,4 \%$ and Southwest region $-14,7 \%$ is lower, which is significantly lower than those of the other four regions (over 20\%). The share of small market-oriented farms in the Northwest region is the highest $(22,6 \%)$, followed by the Northeast region $(22,5 \%)$, North Central (22\%) and Southeast $(20,3 \%)$.

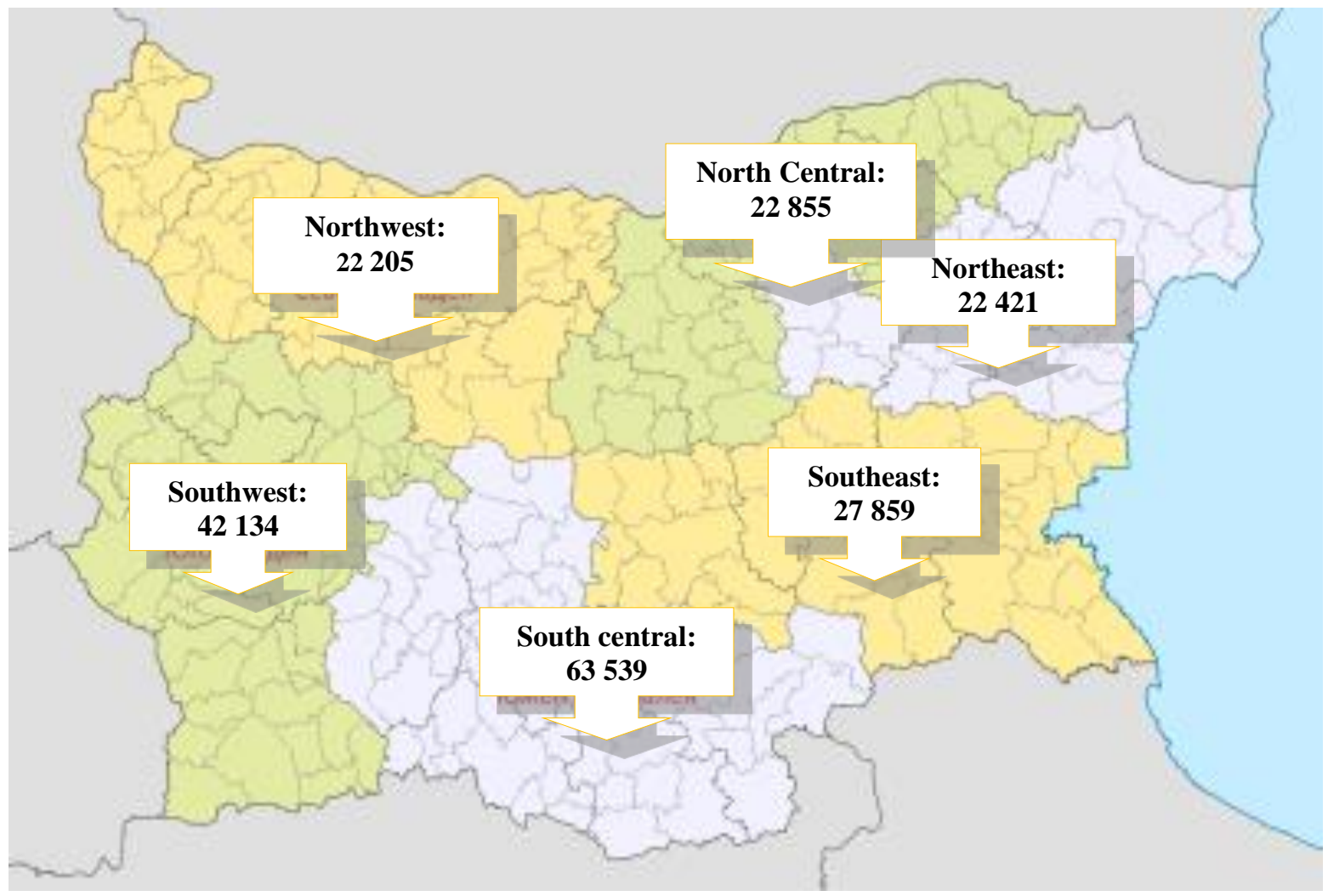

Figure 2. Localization of agricultural enterprises in Bulgaria (number, 2016)

The relative share of large-scale farms in the Northeast region (5\%), North central Region $(4,6 \%)$, Northwest region $(4,4 \%)$, Southeast region $(4,1 \%)$ is much higher as compared to that in Southwest region $(0,7 \%)$ and South
Central region $(1,6 \%)$. These results are mainly related to the significant industrial development of the last two regions as compared to the other four regions in the country. 
ATANASSOVA-KALAYDZHIEVA T.

Table 3. Number and relative share of agricultural enterprises, based on different size groups and planning regions in Bulgaria, 2016

\begin{tabular}{|c|c|c|c|c|c|c|c|c|c|c|c|c|}
\hline \multirow{2}{*}{$\begin{array}{l}\text { Size groups based } \\
\text { on standard output } \\
\text { (EUR) }\end{array}$} & \multicolumn{2}{|c|}{ Northwest } & \multicolumn{2}{|c|}{$\begin{array}{l}\text { North } \\
\text { Central }\end{array}$} & \multicolumn{2}{|c|}{ Northeast } & \multicolumn{2}{|c|}{ Southeast } & \multicolumn{2}{|c|}{$\begin{array}{l}\text { South } \\
\text { central }\end{array}$} & \multicolumn{2}{|c|}{ Southwest } \\
\hline & number & $\%$ & number & $\%$ & imber & $\%$ & umber & $\%$ & umber & $\%$ & number & $\%$ \\
\hline $\begin{array}{l}\text { Small (Subsistence } \\
<2000 \text { ) }\end{array}$ & 10347 & 46.6 & 10170 & 44.5 & 774 & 3.6 & 13393 & 48.1 & 5778 & 56.3 & 5435 & 60.4 \\
\hline $\begin{array}{l}\text { Semi- } \\
\text { ıce }>=2000\end{array}$ & 14 & .7 & 902 & 7.1 & 54 & 6.7 & 93 & .1 & 622 & 19.9 & 440 & 17.7 \\
\hline $\begin{array}{l}\text { Small: (market- } \\
\text { oriented } \\
>=4000<15000)\end{array}$ & 30 & 22.6 & 5032 & 22 & 5043 & 22.5 & 5652 & 20.3 & 9754 & 15.4 & 6191 & 14.7 \\
\hline $\begin{array}{l}\text { Medi } \\
15000 \\
\end{array}$ & 2809 & 12 & 2698 & 11.9 & 2741 & 12.3 & 1 & 12.5 & 4415 & & 2734 & 6.5 \\
\hline Large: $(>=100000$ & 9 & 4 & 1 & $\mathbf{0}$ & 1108 & 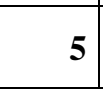 & 1131 & 4.1 & 970 & 1.6 & 334 & 0.7 \\
\hline TOTAL & 22205 & 100,0 & 22855 & 100,0 & 22421 & 100,0 & 27859 & 100,0 & 63539 & 100,0 & 42134 & 100,0 \\
\hline
\end{tabular}

Source: Ministry of Agriculture and Food, Agrarian Statistics Department and author's calculations

Production specialization of agricultural enterprises from different size groups in Bulgaria is presented in Table 4. There is a difference in the established production specialization between small and mediumsized farms on the one hand, and the largescale ones on the other. The leading production specialization in small semisubsistence and market-oriented farms is the raising of grazing animals, swine, poultry and rabbits, $38 \%$ and $33 \%$ respectively of the production in the size group. In the group of the medium-sized farms in Bulgaria the share of those, specializing in animal husbandry (grazing animals, swine, poultry and rabbits) is also $38 \%$. However, the relative share of those growing field crops is higher $-42 \%$. On the contrary, in the group of large-scale farms $71 \%$ are specialized in growing field crops and only $11 \%$ specialize in animal raising (raising of grazing animals), while $7 \%$ raise swine, poultry and rabbits.

Table 4. Relative share of specialized and non-specialized agricultural enterprises in Bulgaria, differentiated according to size groups, $2016(12-18,20)$

\begin{tabular}{|c|c|c|c|c|c|c|c|c|c|}
\hline \multirow{2}{*}{$\begin{array}{l}\text { Size groups based on } \\
\text { standard output } \\
\text { (EUR) }\end{array}$} & \multicolumn{5}{|c|}{$\begin{array}{c}\text { Relative share of } \\
\text { specialized agricultural enterprises, } \\
\text { growing }(\%)\end{array}$} & \multicolumn{3}{|c|}{$\begin{array}{c}\text { Relative share of } \\
\text { non-specialized agricultural } \\
\text { enterprises with prevailing } \\
\text { production }(\%):\end{array}$} & \multirow[t]{2}{*}{$\begin{array}{c}\text { Total } \\
(\%)\end{array}$} \\
\hline & 望 & 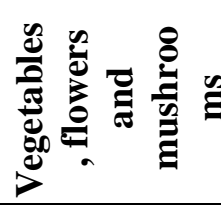 & 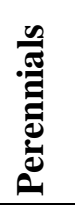 & 占 & 咅高 & 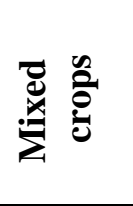 & 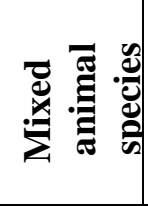 & 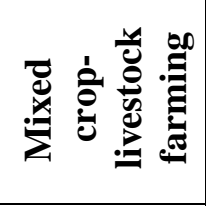 & \\
\hline Small: $($ Subsistent $<2000)$ & 19 & 2 & 16 & 30 & 4 & 3 & 10 & 17 & 100 \\
\hline $\begin{array}{l}\text { Small:-(Semi-subsistent } \\
>=2000<4000)\end{array}$ & 16 & 4 & 10 & 33 & 5 & 5 & 6 & 22 & 100 \\
\hline $\begin{array}{l}\text { Small: (market-oriented } \\
>=4000<15000)\end{array}$ & 28 & 7 & 7 & 30 & 3 & 5 & 2 & 18 & 100 \\
\hline $\begin{array}{l}\text { Medium-sized: }(>=15000 \\
\quad<100000)\end{array}$ & 42 & 5 & 5 & 37 & 1 & 3 & 0.3 & 7 & 100 \\
\hline $\begin{array}{l}\text { Large-scale: (Market- } \\
\text { oriented } \\
>=100000=>250000)\end{array}$ & 71 & 2 & 2 & 11 & 7 & 1 & 0.1 & 5 & 100 \\
\hline TOTAL for Bulgaria & 25 & 4 & 12 & 31 & 4 & 3 & 7 & 14 & 100 \\
\hline
\end{tabular}

Source: Ministry of Agriculture and Food, Agrarian Statistics Department and author's calculations 
Typical for small farms in Bulgaria is the growing of vegetables, flowers, mushrooms and perennials - 7\% of all farms in the group, as compared to medium-sized farms - only $5 \%$ of all farms in the group. This specialization in large-scale farms is insignificant - only $2 \%$ of all farms in the group. Production specialization of large-scale groups is associated with the cultivation of more agricultural land and the possession of modern agrarian equipment. On the contrary, labourintensive and low mechanized vegetable growing, floriculture, mushroom and fruit growing are practiced in small farms, mainly with the involvement of family labour force.

There is another peculiarity of small agrarian farms in the country - the share of non-specialized ones is relatively high: $5 \%$ of all farms in the group grow mixed field crops; $2 \%$ raise different species of farm animals, while $18 \%$ practice mixed crop-livestock farming. On the contrary, in the group of medium-sized and large-scale farms these shares are relatively lower- $1 \%, 3 \%$ and $0,3 \%$ for the medium-sized group and $1 \%, 0,1 \%$ and $5 \%$ for the large-scale group respectively. Production specialization, requiring a large portion of manual work prevail in small farms, while in medium-sized and especially in largescale farms the production specialization is based on a high degree of mechanization.

Total standard output and its relative share for different size groups of farms, both for the separate regions and for the country as a whole, is presented in Table 5.

Small farms in the Northwest, North Central and Northeast regions have almost the same relative shares of standard output $5,6 \% ; 5,4 \%$ and $5,5 \%$. Slightly higher is the standard output share in the Southeast region - 6,2\%; the same share is relatively higher in the Southwest region- $17,1 \%$.

The situation of standard output production is different in large-scale farms. The highest is the relative share of the indicator in the Northeast region - 78, $7 \%$ and the North Central region $78,6 \%$. Then come the Northwest region $-77,1 \%$, the Southeast region-72,6\%, while the Southwest region has the smallest standard output indicator$32,6 \%$ (below that of the medium-sized farms, located in the same territory). The differences found come as a result of the different degree of specialization of the farms and the resulting earning capacity.

In the South central region, on the average, a small market-oriented farm has the lowest standard output indicator per year - EUR 7314; the same indicator is the highest in the Southwest region EUR 8097. In the other four regions the standard output of a small farm is in the range of EUR 7700
- EUR 7900 per year. Regional differences in the standard output indicator are also observed in medium-sized and large-scale agricultural enterprises. The indicator is the highest in the medium-sized and large-scale farms in the Northwest region - EUR 36 thousand and EUR 547 thousand respectively per year; he lowest standard output indicator is observed in the Southwest region - EUR 34 thousand for the medium-sized farms and EUR 268 thousand for the large ones. In the remaining regions, the differences in the standard output indicator for medium-sized farms are negligible, while for large-scale enterprises they are in the range of EUR 542 thousand - EUR 362 thousand.

The main conclusions that may be drawn from the analysis above are as follows:

- In Bulgaria, despite the country being a member of the European Union, the differentiation between small, medium-sized and large-scale agricultural enterprises continues. On the one hand, there is a large group of small farms $86,5 \%$ of all farms in the country (subsistent, semi-subsistent and market-oriented), handling about $1 / 3$ of the utilized agricultural area (UAA). On the other hand, there are fast-growing largescale corporate farms $(3,4 \%)$, which, together with the medium-sized ones (about $10 \%$ of all farms), handle $2 / 3$ of the UAA $(66,1 \%)$.

- $\quad$ Small market-oriented farms are a permanent and stable group in the overall organizational structure of Bulgarian agriculture. The role and importance of this size group of farms are stronger in the regions with poorer industrial development, as they provide their owners with year-round employment and basic income. Because of the importance of small market-oriented farms, especially in rural areas, and for the sake of their sustainable development, a long-term national and regional policy is need.

Large-scale agrarian business is located in the regions with poorer industrial development, providing full-time employment to the local population.

In contrast, small subsistence and semisubsistence farms dominate in the industrially developed regions of the country. Their role is to provide their owners with additional employment and income, as well as to produce agrarian products for the farmer's family.

The disproportion of standard output, produced by a farm per year is also increasing. The highest SO in small market-oriented farms is 68 times lower than same indicator in the large ones, and 4,5 times lower than that in the mediumsized farms. 
Table 5. Total standard output in farms from different size groups, located in different regions in Bulgaria, 2016

\begin{tabular}{|c|c|c|c|c|c|c|c|c|c|c|c|c|}
\hline \multirow{2}{*}{$\begin{array}{l}\text { Region } \\
\text { Size groups based on } \\
\text { standard output of } \\
\text { EUR }\end{array}$} & \multicolumn{2}{|c|}{ Northwest } & \multicolumn{2}{|c|}{ North central } & \multicolumn{2}{|c|}{ Northeast } & \multicolumn{2}{|c|}{ Southeast } & \multicolumn{2}{|c|}{ South central } & \multicolumn{2}{|c|}{ Southwest } \\
\hline & $\begin{array}{c}\text { SO } \\
\text { Thousands } \\
\text { of EUR }\end{array}$ & $\%$ & $\begin{array}{c}\text { SO } \\
\text { Thousands } \\
\text { of EUR }\end{array}$ & $\%$ & $\begin{array}{c}\text { SO } \\
\text { Thousands } \\
\text { of EUR }\end{array}$ & $\%$ & $\begin{array}{c}\text { SO } \\
\text { Thousands } \\
\text { of EUR }\end{array}$ & $\%$ & $\begin{array}{c}\text { SO } \\
\text { Thousands } \\
\text { of EUR }\end{array}$ & $\%$ & $\begin{array}{c}\text { SO } \\
\text { Thousands } \\
\text { of EUR }\end{array}$ & $\%$ \\
\hline $\begin{array}{l}\text { Small: (Subsistent } \\
<2 \text { 000) }\end{array}$ & 9730 & 1.4 & 10112 & 1.4 & 9669 & 1.3 & 11605 & 1.7 & 33548 & 5.2 & 22979 & 8.4 \\
\hline $\begin{array}{l}\text { Small: (Semi-subsistent } \\
>=2000<4000)\end{array}$ & 8907 & 1.3 & 10777 & 1.5 & 10874 & 1.5 & 11928 & 1.7 & 35593 & 5.5 & 20877 & 7.6 \\
\hline $\begin{array}{l}\text { Small (Market-oriented } \\
>=4000<15000)\end{array}$ & 38880 & 5.6 & 39390 & 5.4 & 39901 & 5.5 & 43788 & 6.2 & 71346 & 11.0 & 50133 & 17.1 \\
\hline $\begin{array}{c}\text { Medium-sized }(>=15 \\
000<100000)\end{array}$ & 101407 & 14.6 & 95695 & 13.1 & 95411 & 13.0 & 124399 & 17.8 & 155229 & 24.0 & 94245 & 34,3 \\
\hline $\begin{array}{l}\text { Large: }(>=100000= \\
>250000)\end{array}$ & 533403 & 77.1 & 571673 & 78.6 & 582 & 78.7 & 510094 & 72.6 & 351731 & 54.3 & 89573 & 32.6 \\
\hline TOTAL for Bulgaria & 692327 & 100,0 & 727647 & 100,0 & 732437 & 100,0 & 701814 & 100,0 & 647441 & 100,0 & 274807 & 100,0 \\
\hline
\end{tabular}

Source: Ministry of Agriculture and Food, Agrarian Statistics Department and author's calculations 
3. BASIC GUIDELINES FOR GROWTH AND SUSTAINABLE DEVELOPMENT OF AGRICULTURAL ENTERPRISES IN BULGARIA

In order to overcome the growing differentiation between small and large farms in Bulgaria in the second programming period of implementing CAP mechanisms (20142020 г.), there was a change in the criteria for receiving direct payments, targeted at $(8,21)$ :

- Reduction of direct payments for amounts over EUR 150 thousand by c 5\%, and for amounts over EUR 300 thousand by $100 \%$;

- $\quad$ Size threshold for farms, receiving direct payments was set as follows: for 2015 up to 3884 hectares; for 2016 - 2018 up to 2561 hectares; for 2019 - 2020 up to 2537 hectares;

- A scheme for small farms (not smaller than $0,5 \mathrm{ha}$ ) was introduced, giving them the right to receive up to $10 \%$ of the direct payment ceiling;

An incentive scheme for young farmers was adopted, giving them the right to receive $0,5 \%$ of the national ceiling for direct payments, and providing support for the first 30 ha, etc.

Positive results and changes were achieved during the programming period, but other measures that stimulate growth and development can be added, especially for small market-oriented farms:

\subsection{Encouraging young people to establish and develop a family agrarian business}

If young people are to establish and develop family agrarian business, they should be trained in entrepreneurial skills and culture throughout their education (from elementary, primary, secondary to higher). This may be achieved by teaching subjects, expanding their knowledge and skills for establishing and managing their own farm and others, giving them knowledge on the production technologies, its peculiarities, the risks associated with that, etc. On the one hand, it is possible for schools and universities to build farms for education and practical training. On the other hand, practical seminars and on-the -job practical training may be conducted in successfully developing agrarian holdings in the country and abroad, using the opportunities provided by the Erasmus+ Programme and other European programmes.

3.2. Collaboration of agrarian enterprises with research institutes and universities
ATANASSOVA-KALAYDZHIEVA T. with the aim of introducing technology modernization and innovations

More intensive co-operation between farms and research institution and universities is needed in the development of applied science projects, funded by national and EU operational programmes. A practice of periodically expanding the knowledge of farm workers through participation in courses, seminars and scientific and practical forums, organized by secondary schools, universities and scientific institutions must me established.

Innovative culture of farmers can be improved through the exchange of good practices of introducing new production technologies, new plant varieties and animal breeds, better marketing approach, etc. between Bulgarian and European farms. It is necessary to improve the research and development activities in the agrarian sector through active co-operation between agricultural enterprises and research centers. Such co-operation shall provide opportunities for the introduction of innovations and is also a prerequisite for providing access of agrarian products to new markets.

\subsection{Access to new markets for the Bulgarian agrarian products}

Agricultural institutions must stimulate the development of agrarian products for which the country has favorable natural and climatic conditions, established traditions, experience and a profitable market demand. Farms must be stimulated to produce traditional for our country agrarian products, for which there is demand both on the domestic and foreign markets

Farmers must be assisted in implementing the European quality standards for Bulgarian agrarian products as a prerequisite for their successful market realization in the EU member states. Stock exchange trade of agrarian products must be expanded.

\subsection{Turning environmental challenges into opportunities}

It is necessary to extend the scope of agricultural holdings, financially supported for the introduction of green production technologies and certification of organic plant and livestock products. Prosperity and development will have this agrarian business that systematically discovers and exploits its potential by introducing nature-friendly technologies, underlying the green economy in the $21 \mathrm{st}$ century.

\section{CONCLUSION}

Over the past three decades since the beginning of the socio-economic transformations in Bulgaria, the newly-built farms, in their varied size differentiation, have taken their place in the 
structure of agrarian production and have established themselves in the domestic market. The admission of Bulgaria to the EU in 2007 and the implementation of the mechanisms of the Common Agricultural Policy also contributed to this process.

Large-scale and medium-sized agrarian enterprises are characterized with higher potential for developing a modern agrarian business as compared to the small marketoriented farms. That is why national policy should be oriented towards adopting measures for the growth and modernization of small market-oriented farms. Only through long-term impacts and consistent measures can their sustainable development be guaranteed, which will increase the permanent employment of rural people, help stabilize the local economy, and raise the standard of living of the population.

\section{REFERENCES}

1. Structure and dynamics of EU farms: changes, trends and policy relevance Farm structures, EU Agricultural Economics Briefs., 9., 2013.

2. Davidova, S., Thomson, K., Family farming in Europe: challenges and prospects., Directorate General for Internal Policies, Policy Department B: Structural and Cohesion Policies. European Parliament's Committee on Agriculture and Rural Development, Brussels., 2014.

3. Davidova, S., Fredriksson, L., Gorton, M., Mishev, P. \& Petrovici, D., Comparative Analysis of the contribution of subsistence production to household incomes in five EU New Member States: Lessons learnt. In: Buchenrieder, G. \& Möllers, J., (eds.) Structural change in Europe's rural regions - Farm livelihoods between subsistence orientation, modernization and non-farm diversification., Studies on the Agricultural and Food Sector in Central and Eastern Europe, Vol. 49. IAMO, Halle (Saale), Germany., 2009.

4. Galluzzo, N., Technical and economic efficiency analysis on Italian small holder family farms using Farm accountancy data network dataset. Studies in Agricultural Economics 117, pp. 35-42., 2015.

5. Papadopoulos, A., The impact of the CAP on agriculture and rural areas of EU-member states. Agrarian South: Journal of Political Economy 4, pp. 22-53., 2015.

6. Hazell, P., Poulton, C., Wiggins, S., Dorward, A., The Future of Small Farms: Trajectories and Policy Priorities. World Development 38 (10), pp.1349-1361., 2010.
7. Lowder, S.K., Skoet, J., Raney, T., The Number, Size, and Distribution of Farms, Smallholder Farms, and Family Farms Worldwide. World Development. 87, p.1629., 2016.

8. Koteva N. and M. Atanasova-Chopeva, The role of small farms in the context of Euro integration, Economics and management of agriculture 56., 5., pp.33-35., 2011.

9. Authie E., C. Berg, A. Botner, H. Browman and others., Scientific Opinion on the assessment of dairy cow welfare in smallscale farming systems. European Food Safety Authority Journal. 13 (6). pp. 12-25., 2015.

10. Agrarian Accounting Information System, Final results, Ministry of Agriculture and Food, Sofia., pp.8., 2013.

11. Regulation EU 2015/220, using the Standard output indicator (standard outputs (SO)).

12. Methodological report - Agricultural Accounting Information System., Ministry of Agriculture and Food, Sofia., 2016.

13. Survey of the structure of farms in 2016, Report - Ministry of Agriculture and Food., Sofia., 2017.

14.CAP 2015 - 2020: Small farmer scheme, Ministry of Agriculture and Food, Direct payment and market support Directorate, Sofia, pp.1-9., 2015.

15.CAP, direct payments 2015-2020., Reportpresentation of Ministry of Agriculture and Food, Direct payments and market support Directorate, Sofia., 2016.

16. Analysis of the potential effect of applying a redistribution payment scheme in Bulgaria in 2014, Report - Ministry of Agriculture and Food, Sofia., 2014.

17. Atanassova-Kalaydzhieva T., Development of agrarian farms in Bulgaria and the influence of EU's CAP. „EU's CAP and the agribusiness in the Republic of Bulgaria economic and legal issues"., D. Tsenov Academy of Economics, Svishtov., pp.7782., 2016.

18. Farm structure survey, Report - Ministry of Agriculture and Food. Sofia., 2016.

19. Kaneva K., Institutional changes and structural reform in agrarian farms, Monograph, Sofia., 2015.

20.Guiomar, N., Godinho, S. and odher., Typology and distribution of small farms in Europe: Towards a better picture., Land Use Policy 75., pp. 784-798., 2018.

21. Direct payments and marker support - reportpresentation, CAP, direct payments 20152020. Ministry of Agriculture and Food., Sofia., 2015. 